\title{
NOTE
}

\section{THE CONTRACTUAL OBLIGATIONS OF A SUCCESSOR EMPLOYER UNDER THE COLLECTIVE BARGAINING AGREEMENT OF A PREDECESSOR}

For labor law the vital concern is the employment relationship.. . rather than the concept of legal identity and privity of contract. The nature of our economic structure and life has led to the development of new concepts of successorship applicable to labor contracts. ${ }^{1}$

\section{Application of a New Labor Analysis}

In 1964 in John Wiley \& Sons v. Livingston, ${ }^{2}$ the Supreme Court held that a successor employer ${ }^{3}$ was obligated under a collective bargaining agreement to arbitrate a dispute with the union even though the successor was neither a party to the agreement nor assumed its obligations. Before expiration of a collective bargaining agreement, the predecessor employer merged with the successor and ceased doing business as a separate entity. The union took the position that it continued to represent the predecessor's employees, that the successor was bound by the predecessor's collective bargaining agreement, and that after its expiration the successor was obligated to recognize certain employee rights which had vested under the agreement. ${ }^{4}$ Because the agreement contained an arbitration clause, the union, shortly before the contract expired, brought suit to compel arbitration of these disputes.

In support of its claims, the union relied on the New York Stock Corporation Law which provided that no "claim or demand for any cause" against a corporation shall be extinguished by consolidation. ${ }^{5}$ In the alternative the union argued that, given a policy favoring arbitration, the federal common law should not allow changes in corporate organization to undermine that policy. The successor contended that it was never a party to the agreement, which in any event was terminated by the merger.

1 Walker Bros., 41 Lab. Arb. 844, 848 (1963).

2376 U.S. 543 (1964).

3 The term successor is used throughout this note to refer broadly to the resulting employer after a purchase, merger, or consolidation.

4 The union argued that the successor employer was obligated to recognize seniority rights accrued during employment with the predecessor, to make pension fund contributions, to honor job security and grievance provisions of the agreement, and to make severance and vacation payments. 376 U.S. at 552.

5 N.Y. STOCK CORP. LAW $\S 90$. 
The Court declined to decide whether the successor was bound by the substantive provisions of the predecessor's agreement. It decided only that the successor was obligated to arbitrate the successorship issue as well as the substantive questions of contract interpretation. This result is consistent with heretofore unchallenged principles of corporation-contract law that although a successor is not bound by the contracts of the predecessor employer following a purchase of the predecessor's business, the successor is bound by such contracts after a merger in which the predecessor's business is absorbed into that of the successor. ${ }^{6}$ Although Wiley involved a merger situation, the Supreme Court brushed aside this narrow ground of decision, stating that it was not bound by state law, ${ }^{7}$ and held that it was to apply or fashion federal law in actions for breach of contract brought under section 301 of the Labor Management Relations Act. ${ }^{8}$ The Court then launched a new policy, declaring its holding to be applicable "as much in cases like the present, where the contracting employer disappears into another by merger, as in those in which one owner replaces another but the business entity remains the same." 9

The Court recognized that the rightful prerogative of owners to independently rearrange their businesses and even eliminate themselves as employers must be balanced against the need for insuring to the employees a continuity in the protection afforded by their collective bargaining agreement. However, it decided that national labor policy renders paramount the employee interest.

This decision represents in part an extension of the policy set forth by the Court in United Steelworkers v. Warrior \& Gulf Nav. Co.:10 arbitration as a substitute for industrial strife is an integral part of the collective bargaining process, and federal policy favors amicable settlements of labor disputes rather than resort to the relative economic strength of the contestants. In recognition of this policy, the Court in Wiley declared that even though ordinary contract law would not require the successor to fulfill the obligations of the predecessor's collective bargaining agreement,

6 See generally Ballantine, Corporations $\$$ 280-82, 287, 289 (rev. ed. 1946); 15 Fletcher, Private Corporations \$\$ 7117, 7121-22, 7125 (Wolf rev. ed. 1961).

7376 U.S. at $547-48$.

8 Textile Workers Union v. Lincoln Mills, 353 U.S. 448, 456 (1957). Section 301(a) of the Labor Management Relations Act states:

Suits for violation of contracts between an employer and a labor organization representing employees in an industry affecting commerce... or between any such labor organization, may be brought in any district court of the United States having jurisdiction of the parties, without respect to the amount in controversy or without regard to the citizenship of the parties.

Labor Management Relations Act (Taft-Hartley Act) §301(a), 61 Stat. 156 (1947), 29 U.S.C. \& 185 (1958).

8376 U.S. at 549. It is significant that following Wiley, two courts of appeals feit compelled to reverse decisions reached prior to $W$ iley. United Steelworkers v. Reliance Universal, Inc., 335 F.2d 891 (3d Cir.), reversing 227 F. Supp. 843 (W.D. $\mathrm{Pa}$ 1964); Wachenhut Corp. v. International Union, Plant Guard Workers, 332 F.2d 954 (9th Cir.), reversing on rehearing 55 I.R.R.M. 2554 (9th Cir. 1964). These reversals indicate that $W$ iley is thought to require a new analysis.

10363 U.S. 574 (1960). 
such an agreement is not an ordinary contract. ${ }^{11}$ Warrior declared that a collective bargaining agreement is a generalized code to govern a myriad of cases which the draftsmen cannot wholly anticipate. The agreement embraces the entire employment relationship and calls into being a new common law, the common law of a particular industry or plant. Because of the policy underlying the requirements of the National Labor Relations Act,,$^{12}$ the collective bargaining agreement is not necessarily the product of a consensual relationship.

Given these policy considerations, the duty to arbitrate should not be automatically overridden by the absence of the successor's signature on the agreement. Surely, it is not as if the successor is a total stranger to the agreement. Although the duty to arbitrate, under formal contract principles, is based solely on the contract, such principles should not be applied too strictly in the present context at the expense of pervasive labor policy goals.

Thus, while Warrior primarily involved a fashioning of federal labor law, Wiley presented a choice between applying existing contract-corporation law principles or fashioning federal labor law. By requiring the successor to arbitrate the dispute, the Court chose the latter.

The purposes of this Note will be to examine the continued relevance of the pre-Wiley law concerning the obligations of the successor to a business; to consider the Wiley rule, its rationales and applications by the lower federal courts; and, finally, to consider the potential impact of Wiley upon the collective bargaining process and upon the commercial practices of business transfers.

\section{Legat Background of Wiley}

Although Wiley represents a mandate for the development of a federal common law governing the enforcement of collective bargaining agreements against successor employers, similar issues have previously arisen in a variety of contexts. The Court in Wiley, citing Textile Workers Union v. Lincoln Mills, ${ }^{13}$ stated that "state law may be utilized so far as it is of aid in the development of correct principles or their application in a particular case . . . but the law which ultimately results is federal." 14

11376 U.S. at 550; see Chamberlin, Collective Bargaining and the Concept of Contract, 48 Colum. L. REv. 829 (1948) ; Cox, Rights Under a Labor Agreement, 69 Harv. L. Rev. 601, 605 (1956); Summers, Judicial Review of Labor Arbitration, 2 Bufralo L. Rev. 1, 17-18 (1952).

12 An employer is prohibited by law from hiring employees on the basis of their membership or nonmembership in a labor organization. National Labor Relations Act (Taft-Hartley Act) $\$ 8(\mathrm{a})(3)$, as amended, 73 Stat. 525 (1959), 29 U.S.C. 158(a) (3) (Supp. IV, 1963).

When the union represents the majority of the employees, the employer must negotiate with the union and must make a sincere effort to reach an agreement. National Labor Relations Act (Taft-Hartley Act) § 8(a) (5), 61 Stat. 141 (1947), 29 U.S.C. 158 (a) (5) (1958).

13353 U.S. 448,457 (1957).

14376 U.S. at 548. 
To the extent that other authority can implement the policies set forth in Wiley, it should continue to be considered by the courts.

\section{A. Conmon-Law Commercial Doctrines}

With respect to a sale of corporate assets, the courts have held that the purchaser is not obligated to perform the collective bargaining agreement of the predecessor employer. ${ }^{15}$ The grounds for this rule appear to be the courts' identical treatment of these agreements and the claims of the seller's creditors ${ }^{16}$ and the lack of privity of contract between the union and the purchaser. ${ }^{17}$ There have been, however, several exceptions to the rule. The collective bargaining agreement is binding: when the transaction was not in good faith, but was designed to enable the seller to avoid his obligations; ${ }^{18}$ when the successor is regarded as a mere alter ego of the predecessor, as when the predecessor organization is continued in a slightly changed form; ${ }^{19}$ when the successor has expressly or impliedly assumed the predecessor's obligations; ${ }^{20}$ and one court has given effect

15 See International Longshoreman's Union v. Juneau Spruce Corp., 189 F.2d 177 (9th Cir. 1951), aff'd on other grounds, 342 U.S. 237 (1952); International Ass'n of Machinists v. Shawnee Indus., Inc., 224 F. Supp. 347 (W.D. Okla. 1963) ; Livingston v. Gindoff Textile Corp., 191 F. Supp. 135 (S.D.N.Y. 1961) ; Office Employees Union v. Ward-Garcia Corp., 190 F. Supp. 448 (S.D.N.Y. 1961); Gold v. Gibbons, 178 Cal. App. 2d 517, 3 Cal. Rptr. 117 (Dist. Ct. App. 1960) ; Tarr v. Amalgamated Ass'n St. Elec. Ry. Employees, 73 Idaho 223, 250 P.2d 904 (1952); Berry v. Old South Engraving Co., 283 Mass. 441, 186 N.E. 601 (1933) ; Carauso v. Empire Case Goods Co., 297 N.Y. 514, 74 N.E.2d 462, 63 N.Y.S.2d 35 (1947); Answerite, Inc. v. United Tel. Union, 55 L.R.R.M. 2867 (N.Y. Sup. Ct. 1964) ; In re Gray Line Motor Tours, 50 L.R.R.M. 2473 (N.Y. Sup. Ct. 1962); In re International Ass'n of Machinists, 34 Misc. 2d 645, 229 N.Y.S.2d 476 (Sup. Ct. 1962); Robertson v. Midland Windsor, Inc., 116 N.Y.S.2d 544 (Sup. Ct. 1952); In re Swift \& Co., 76 N.Y.S.2d 881 (Sup. Ct. 1947); International Ass'n of Machinists v. Falstaff Brewing Corp., 328 S.W.2d 778 (Tex. Civ. App. 1959); Menominee Sugar Co., 53 L.R.R.M. 1167 (Wis. Empl. Rel. Bd. 1963). $\S 7122$.

16 Ballantine, op. cit. supra note $6, \S 287 ; 15$ Fletcher, op. cit. supra note 6 ,

17 See Starpson, Contracts $\$ 81$ (1954).

18 See International Ass'n of Machinists v. Shawnee Indus., Inc., 224 F. Supp. 347 (W.D. Okla. 1963); Answerite, Inc. v. United Tel. Union, 55 L.R.R.M. 2867 (N.Y. Sup. Ct. 1964) ; Herman Loewstein, Inc., 75 N.L.R.B. 377 (1947) (dictum); BALLANInNe, op. cit. supra note $6, \S 287 ; 15$ FLETCHER, op. cit. supra note $6, \$ \S 7122$, 7125.

19 See United Shoe Workers v. Brooks Shoe Mfg. Co., 183 F. Supp. 568 (E.D. $\mathrm{Pa}$. 1960) (one member of a partnership became the new employer); Kraft $\mathrm{v}$. Garfield Park Community Hosp., 296 I11. App. 613, 16 N.E.2d 936 (1938) (new incorporation of an old corporation); In re Reif., 9 N.Y.2d 387, 174 N.E.2d 492, 214 N.Y.S.2d 395 (1961) (partnership formed a corporation); BALLANTINE, op. cit. supra note $6, \S 287 ; 15$ FLETCHER, op. cit. supra note $6, \S 7122$.

However, some courts have been reluctant to apply this exception. See Livingston v. Gindoff Textile Corp., 191 F. Supp. 135 (S.D.N.Y. 1961) (shareholders and employees formed a new corporation); Berry v. Old South Engraving Co., 283 Mass. 441, 186 N.E. 601 (1933) (officers and directors reorganized the corporation); In re International Ass'n of Machinists, 34 Misc. 2d 645, 229 N.Y.S.2d 476 (Sup. Ct. 1962) (corporation divided into two corporations).

20 See NLRB v. International Hod Carriers, 287 F.2d 605 (9th Cir. 1961) ; United Steelworkers v. Copperweld Steel Co., 230 F. Supp. 383 (W.D. Pa. 1964); International Ass'n of Machinists v. Shawnee Indus., Inc., 224 F. Supp. 347 (W.D. Okla. 1963); Hotel Cecil, 23 War Lab. Rep. 542 (Nat'1 Bd. 1945); see Ballantrine, op. cit. supra note $6, \S 287$; FLETCHER, op. cit. supra note $6, \S 7122$. 
to a clause inserted into a collective bargaining agreement purporting to bind any successors to the employer. ${ }^{21}$ However, these exceptions are of limited scope. In most situations the successor is a distinct legal identity making a valid good-faith purchase. Even when the exceptions might be applied, the courts have tended to construe them narrowly. The general rule has therefore remained one of considerable impact.

In contrast to the rules applying to a sale of assets, successors following a merger or a consolidation have generally been bound to perform the obligations of their predecessors. ${ }^{22}$ Most litigation in these circumstances has been instituted by ordinary creditors rather than by unions seeking to enforce collective bargaining agreements, but what authority there is suggests that the same rule would be applied to both types of claims. ${ }^{23}$

\section{B. Principles Underlying the Common-Law Rules}

One basis for the rule relieving a purchaser from the obligations of the seller is the ability of his creditors to proceed against the seller. Since the latter has ordinarily received consideration for the sale, ${ }^{24}$ the creditors would be adequately protected. Thus, if the predecessor did not receive consideration or received only stock of the successor, many courts have held that the successor is liable to the creditors of the seller. ${ }^{25}$ Similarly,

21 Polaner v. Gold Medal Grill, Inc., 117 N.E.2d 62 (Ohio C.P. 1961).

However, most courts have held that despite this clause, the successor is not in privity of contract with the union and is not bound in the absence of an assumption of the agreement. See Gold v. Gibbons, $178 \mathrm{Cal}$. App. 2d 517, 3 Cal. Rptr. 117 (Dist. Ct. App. 1960) ; In re Swift \& Co., 76 N.Y.S.2d 881 (Sup. Ct. 1947) ; International Ass'n of Machinists v. Falstaff Brewing Corp., 328 S.W.2d 778 (Tex. Civ. App. 1959).

22 See Ballantine, op. cit. supra note $6, \$ \S 280-82,287,289$ \& cases cited; 15 Fletcher, op. cit. supra note $6, \S \S 7117,7121-22$ \& cases cited. The result is compelled by statute in some jurisdictions. E.g., DeL. Code ANN. tit. 8, §259 (1953); N.Y. Stock CoRp. Law $\$ \S 85(2), 90$; OHio Rev. Code AnN. tit. 17, $\$ 1701.81$ (A) (6) (Page 1964) ; PA. Stat. Ann. tit. 15, §2852-907 (Supp. 1964).

23 The War Labor Board directed that the parties insert clauses in their collective bargaining agreements binding successors following mergers or consolidations. See Remington Rand, Inc., 13 War Lab. Rep. 726 (Regional Bd. II, 1943); New England Shipbuilding Corp., 8 War Lab. Rep. 911 (Shipbuilding Comm'n 1943); cf. Chipman v. Turner, Day \& Woolworth Mfg. Co., 32 Ky. L. Rep. 680, 106 S.W. 852 (Ct. App. 1908) (individual employment contract).

Additional support for this rule can be found in a decision concerning a merger in the communication industry. Commercial Telegraphers Union $v$. Western Union Tel. Co., 53 F. Supp. 90, 96-97 (D.D.C. 1943). The controlling statute authorizing mergers indicated a policy favoring the protection of employee rights, although it did not require that the successor assume the collective bargaining agreement of the predecessor. Communications Act $\S 222$ (f), added by 57 Stat. 8 (1943), 47 U.S.C. $\$ 222$ (1958).

24 See American Ry. Express Co. v. Commonwealth, $190 \mathrm{Ky} .636,228$ S.W. 433 (1920) ; 44 Harv. L. Rev. 260 (1930) ; 26 Mrch. L. Rev. 913 (1928).

25 Chorpenning v. Yellow Cab Co., 113 N.J. Eq. 389, 167 Atl. 12 (Ch. 1933), aff'd per curiam, 115 N.J. Eq. 170, 169 Atl. 691 (Ct. Err. \& App. 1934) ; Peters v. American Ry. Express Co., 256 S.W. 100 (Mo. Ct. App. 1923) ; American Ry. Express Co. v. Downing, 132 Va. 139, 111 S.E. 265 (1922). Contra, McAlister v. American Ry. Express Co., 179 N.C. 556, 103 S.E. 129 (1920) (shares of successor's stock considered adequate consideration). 
in the case of a consolidation or merger, the only assets that may be available to a creditor will be in the hands of the successor. Accordingly, it has been held that a creditor of the predecessor can reach assets of the predecessor now in the hands of the successor following a consolidation. ${ }^{26}$

The principles determining legal rights and obligations under collective bargaining agreements are not derived from common-law rules of contract, but are to be found in the peculiar needs of labor relations. ${ }^{27} \mathrm{~A}$ union is not interested in a damage award for a total breach of the collective bargaining agreement; its goal is continued performance of the agreement. The predecessor's possession of assets reachable in a damage action will not adequately protect the union or the predecessor's employees. Once he has disposed of the assets of his business, the predecessor can no longer perform, and the successor remains the only party capable of meaningful recognition of rights of union and employees. Since the corporate-contract rules reflect different values than those present in collective bargaining relations, this former body of law would seem to have little continued value in the latter context. However, the exceptions to the general rule may remain apropos. Clearly, a successor who assumes the predecessor's obligations or one who is merely an alter ego of the predecessor would be bound to fulfill the predecessor's obligations; it would not be necessary to apply even the Wiley analysis in these cases. The successor should also be bound to perform if the transaction was fraudulent or not in good faith, even though the Wiley standards were not satisfied.

\section{Representation Election Decisions of the National Labor Relations Board}

The Board has held that a collective bargaining agreement with a union will bar an election petition of another union for a maximum of three years. ${ }^{28}$ Thus the Board must decide whether the successor is bound by a collective bargaining agreement of the predecessor so as to bar an election during its existence. ${ }^{28}$ In such a situation the litigating parties are rival unions: the union which had a collective bargaining agreement with the predecessor employer will argue that the successor employer is bound by the agreement; the union petitioning for the election, which may be an outside union or a union representing some of the employees of the successor employer, will argue that the predecessor's contract is not binding on the successor and therefore not a bar to the election.

The Board has attempted to establish guidelines for determining whether the change in ownership changed the employer-employee bargain-

26 First Nat'l Bank v. Hoover, 269 S.W. 262 (Tex. Civ. App. 1925) ; see Tompkins v. Augusta So. R.R., 102 Ga. 436, 30 S.E. 992 (1897) ; American Ry. Express Co. v. Downing, 132 Va. 139, 111 S.E. 265 (1922).

27 See Chamberlain, supra note 11; Cox, supra note 11, at 604; Summers, supra note 11 , at 17-18.

28 General Cable Corp., 139 N.L.R.B. 1123 (1962).

29 The successorship issue also has come before the Board in deciding whether a successor must honor certification orders. See note 43 infra and accompanying text. 
ing relationship. When the transaction has involved only a transfer of physical assets, as distinct from a purchase of goodwill and other intangible assets, and particularly when no arrangements for the retention of existing employees have been made, the Board has found an insufficient continuity of the employment relationship, so that the predecessor's collective bargaining agreement did not bar an election. ${ }^{30}$ However, when the changes in ownership did not change the employment relationship, as where the employees, supervisors, and operations remained the same, the collective bargaining agreement has been deemed a bar to a new election..$^{31}$

The Board does not seem to distinguish between purchases and consolidations or mergers as did the courts. Rather the Board applies its continuity test uniformly, and if the operations of the successor were not just a continuation of the operations of the predecessor, the agreement of the predecessor will not be a bar..$^{32}$

Although the Board applies basically the same standard that was used in Wiley in deciding the same legal issue presented in that case, the policies are not the same in these two areas. In Wiley the Court was forced to choose between a policy favoring continued union representation and protection by a collective bargaining agreement for the predecessor's employees and a policy promoting the free transfer of property by not compelling a successor to fulfill the obligations of a contract to which he was not a party. However, in the election cases, the Board is concerned with the representation of the employees; the only question before the Board is whether the rival union should have the opportunity to obtain the employees' support. However, this difference in underlying policies should not affect the result. In each situation the same legal issue has been decided by application of the same legal standards to a similar factual context.

\section{War Labor Board Decisions}

The National War Labor Board was a federal agency designed to facilitate the peaceful settlement of disputes between labor and management during World War II, and although it had authority only to propose to the parties solutions to their disputes, these proposals carried considerable weight, given the threat of presidential seizure. ${ }^{33}$ The Board appeared to reach results similar to those of the National Labor Relations Board. When the successor continued operations virtually unchanged, the War Labor Board held that the successor should fulfill the contractual obliga-

30 Maybee Stone Co., 129 N.L.R.B. 487 (1960) ; General Extrusion Co., 121 N.L.R.B. 1165 (1958); Herman Loewenstein, 75 N.L.R.B. 377 (1947); Tampa Transit Lines, Inc., 71 N.L.R.B. 742 (1946).

31 Grainger Bros., 146 N.I.R.B. No. 75 (April 2, 1964) ; cf. Perl Pillow Co., 50 L.R.R.M. 1274 (Regional Director 1962).

32 L. B. Spear \& Co., 106 N.L.R.B. 687 (1953) ; cf. Bowman Dairy, 123 N.L.R.B. 707 (1959) (no change in the successor's operations; therefore, a collective bargaining agreement between successor and a union was a bar to an election petition presented by a union which formerly represented the predecessor's employees). (1946).

33 See generally 1 War Lab. Rep. iii-iv, ix-xviii (1942); 28 War Lab. Rep. i-ii 
tions of the predecessor. ${ }^{34}$ However, when the operations were not continued substantially in the same manner, and when there was no substantial identity between the successor and the predecessor, the successor was held not to be bound by the predecessor's agreement. ${ }^{35}$

\section{E. Arbitration Awards}

The issue of a successor employer's obligations under a collective bargaining agreement has occasionally arisen in arbitration proceedings. However, unlike the successor in Wiley, the successors here will have consented to the submission of the dispute to an arbitrator, contesting only his obligations under the substantive terms of the collective bargaining agreement. The arbitrators have tended to look to the continuity of the employer-employee relationship rather than solely to the alteration in the legal identity of the employer as did the common-law courts. ${ }^{36}$ However, the arbitration decisions have considered as a factor the lack of hardship to the successor, emphasizing, for instance, that the successor has the opportunity to examine the agreement before the transaction, and, if undesirable, he can either adjust its terms or abandon the transaction altogether. ${ }^{37}$

Several factors commend these arbitration awards as authority for the resolution of future litigation. The test of continuity is similar to that suggested by Wiley. Moreover, the parties and issues are similar to those raised in section 301 actions. Finally, the opinions indicate that the arbitrator was concerned with a weighing and balancing of the interests at stake, which is comparable to the mandate given judges by Wiley.

\section{Dispositron of the Successorship Issue}

\section{A. Substantial Continuity of Operations Required}

The Court in Wiley declared that before a successor could be bound to arbitrate under the collective bargaining agreement of the predecessor, there must be substantial continuity of operations, and that the wholesale transfer of employees without difficulty adequately indicates similarity and continuity of operations. ${ }^{38}$ This test closely resembles similar tests used by

34 See Snow Lumber Co., 21 War Lab. Rep. 445 (Regional Bd. IV, 1944), modified, 24 War Lab. Rep. 306 (Nat'l Bd. 1945) ; National Munitions Co., 14 War Lab. Rep. 644 (Regional Bd. III, 1944).

35 Essential Tool \& Die Corp., 12 War Lab. Rep. 589 (Nat'l Bd. 1943) ; Consolidated Vultee Aircraft, 16 War. Lab. Rep. 431 (Regional Bd. X, 1944), modified on other grounds, 21 War Lab. Rep. 188 (Nat'l Bd. 1945) ; cf. Douglas Aircraft Co., 21 War Lab. Rep. 760 (Nat'1 Bd. 1944).

${ }^{36}$ Shapiro Bros. \& Gordon Co., 11 Lab. Arb. 481 (1948) ; City Packing Corp., 11 Lab. Arb. 358 (1948). Di Giorgio Wine Co., 28 Lab. Arb. 746 (1957) (dictum) (held successor not bound to honor individual employee-employment contracts of the predecessor since only collective bargaining agreement survived sale); Cliquot Club Bottling Co., 14 Lab. Arb. 260, 262 (1950) (dictum) (normally a successor is bound but not following a bankruptcy sale). Contra, C-F-M Co., 37 Lab. Arb. 980 (1962). See generally Walker Bros., 41 Lab. Arb. 844 (1963).

37 City Packing Corp., supra note 36 , at 361 .

38376 U.S. at 551. 
the Board ${ }^{39}$ and by arbitrators. ${ }^{40}$ However, the Court's explanation of this test is subject to the same shortcoming as that which limits the usefulness of the Board decisions and arbitration awards: the courts have been confronted only by polar situations, and therefore their decisions are little guide to the resolution of less than clear-cut cases.

Even the unions during litigation have conceded that not every successor must fulfill the predecessor's obligations. ${ }^{41}$ If the successor only purchases equipment, real estate, or other tangible assets, he would not succeed to the employment relationship of the predecessor. On the other hand, in two courts of appeals decisions after Wiley, it appeared that virtually everything at the predecessor's plant continued as before-only the name of the employer changed. ${ }^{42}$ Since the above facts represent the extremities, they shed little light on the workings of the Court's test of continuity.

There are, however, certain NLRB decisions which are valuable in analyzing nonpolar situations. The Board has used a continuity test in deciding whether certification of a union as bargaining representative, obtained while the predecessor was the employer, will compel the successor to bargain with the union in absence of a showing of majority status. ${ }^{43}$ Clearly the question whether a union's representative status survives a change in ownership is not the same as whether an existing collective bargaining agreement survives. However, in both situations, the same parties are involved in the litigation, the same policy of industrial stability is present, and the same legal standard is used in deciding cases. Therefore, the Board's handling of factual variations is of significance in the Wiley context.

The Board in applying the continutity standard seems to have required that five elements remain constant in order for the employment relationship not to have changed: location of the business and similarities of personnel, supervision, equipment, and mode of operations. It is apparent that equipment, mode of operations, and supervision are related to the employeremployee relationship. These elements directly affect the nature of the employee's work and the method for its performance. However, it is not obvious why location of the plant should remain the same. A change in the site of the employment seems unrelated to the employer-employee rela-

39 See notes 28-32 supra and accompanying text.

40 See notes 36-37 supra and accompanying text.

41 Brief for the AFL-CIO as Amicus Curiae, pp. 12-13, John Wiley \& Sons v. Livingston, 376 U.S. 543 (1964) (giving as an example assets sold to auction company for dismantling and resale).

42 United Steelworkers v. Reliance Universal, Inc., 335 F.2d 891, 893 (3d Cir. 1964) ; Wackenhut Corp. v. International Union, Plant Guard Workers, 332 F.2d 954, 957 (9th Cir. 1964).

43 NLRB v. Alamo White Truck Serv., Inc., 273 F.2d 238 (5th Cir. 1959); NLRB v. Lunder Shoe Corp., 211 F.2d 284 (1st Cir. 1954); NLRB v. Albert Armato, 199 F.2d 800 (7th Cir. 1952); Howard Johnson, Inc., 135 N.L.R.B. 1260 (1962); Cruse Motors, 105 N.L.R.B. 242 (1953); Northwest Glove Co., 74 N.L.R.B. 1697 (1947). 
tionship. The Court in Wiley indicated that the employees had been transferred to the successor's plant, ${ }^{44}$ although finding nevertheless a continuity of operations. Grounds therefore exist for dismissing location as a significant factor in determining continuity of operation.

Determination of the pertinence of the successor's retention of the predecessor's employees as a factor presents a more difficult problem. In Wiley the use of the predecessor's employees in the successor's operations without any difficulty was considered adequate evidence of continuity of operations, ${ }^{45}$ and in Herman Lowenstein, ${ }^{46}$ an NLRB contract bar decision, the absence of an agreement by the successor to hire any employees appeared crucial to the Board's finding that no successor relationship existed. However, in Zdonak v. Glidden Co., ${ }^{47}$ it was held that since job and seniority rights continue after the termination of the contract, an employer is required to reemploy his employees at a new plant following relocation of the business. A fortiori, a nonsuccessor employer in relocating would have had to reemploy these employees without loss of seniority if the contract had not expired. Thus it is arguable that a successor who is bound by the collective bargaining agreement of the predecessor would be required to hire the predecessor's employees without loss of seniority; and layoffs, if necessary, would be made according to the contract provisions. ${ }^{48}$ If an employer would be obligated to hire the employees, it is circular to use employment of employees as a standard to determine whether the successor is so bound. A contrary position is that the successor should be bound only if all the elements of continuity of the employment relationship are present, and therefore the successor cannot be bound if the predecessor's employees are not hired. However, if this position were accepted by the courts, it would become easy for a successor to avoid the effect of Wiley. By simply not hiring any of the predecessor's employees, the successor could completely avoid the predecessor's collective bargaining obligations. Since such an escape mechanism could make Wiley meaningless, employment of the predecessor's employees should not be an element of the Wiley test.

\section{B. Under an Arbitration Clause}

Both in Wiley and in the two subsequent decisions, ${ }^{40}$ the collective bargaining agreement contained arbitration clauses, and the suits were brought under section $301^{50}$ to compel arbitration. The Supreme Court

44376 U.S. at 551.

45 Ibid.

4675 N.L.R.B. 377 (1947).

47288 F.2d 99 (2d Cir. 1961), aff'd on other grounds, 370 U.S. 530 (1962).

48 See also Piano \& Musical Instrument Workers v. Kimball Co., 221 F. Supp. 461 (N.D. I11. 1963).

49 United Steelworkers v. Reliance Universal, Inc., 335 F.2d 891 (3d Cir. 1964); Wackenhut Corp. v. International Union, Plant Guard Workers, 332 F.2d 954 (9th Cir. 1964).

50 Labor Management Relations Act (Taft-Hartley Act) §301(a), 61 Stat. 156 (1947), 29 U.S.C. \$185(a) (1958). 
in Wiley declined to make the entire agreement binding on the successor, holding merely that he must arbitrate the dispute concerning the predecessor's agreement. ${ }^{51}$

The Wiley opinion does not articulate the rationale behind the court's refusal to decide the successorship issue and thus leaves considerable doubt as to the proper disposition of cases arising out of different factual contexts.

\section{Wiley Confined to Its Narrow Facts}

One problem immediately presented is whether Wiley precludes the lower federal courts from holding that a successor is bound under the predecessor's collective bargaining agreement. It has been argued that the lower courts would not be so precluded because the court in Wiley could not have directly decided the successorship issue, that arbitration was the only disposition available to the court. ${ }^{52}$ This contention is based on the fact that the agreement had expired; there was no present agreement to be enforced. Thus it is stressed that the union in Wiley was claiming that certain rights had vested ${ }^{53}$ during the life of the agreement and survived expiration of the agreement, and, also, that the duty to arbitrate survived as well. Since whatever rights vest and survive the expiration of an agreement are a matter of contract interpretation, generally decided by the arbitrator, the Court properly declined to go further than to order arbitration.

A second ground for urging that Wiley could not properly have decided that the successor was bound is that the union sought only to compel arbitration, the only contract breach alleged having been the successor's refusal to arbitrate. Thus it could be maintained that the issue whether the successor was bound by the contract was not properly before the court.

However, neither contention fully accounts for the Court's disposition; the Court clearly would have been justified in deciding whether the successor was bound by the collective bargaining agreement. First, although the union was claiming certain vested rights, other rights were not of a vested nature, but had arisen and matured into claims before the expiration of the contract. ${ }^{54}$ Second, before the merits of either type claim could be determined, the successorship issue would need to be resolved. The Court left this issue for the arbitrator even though there is no basis for characterizing this issue as one of contract interpretation, ordinarily a question for the arbitrator. Third, the fact that the union sought only arbitration does not avoid the successorship issue, for if the

51376 U.S. at $550-51$.

52 Brief for Appellees on Rehearing, p. 6, Wackenhut Corp. v. International Union, Plant Guard Workers, 332 F.2d 954 (9th Cir. 1964).

53 Vested rights in this context refer to continuing obligations which an employer is not free to disregard even upon termination of the contract, such as pension payments.

64376 U.S. at 554. 
successor had no contractual obligations, the refusal to arbitrate would not have been a breach. It is therefore clear that Wiley could have decided the successorship issue; that this was not done must be taken into account in formulating any acceptable rationale of the decision.

\section{Judicial Restraint}

The disposition of Wiley is also consistent with the possibility that the Court declined to decide the successorship issue because it believed a ruling on this issue to be superfluous, the agreement having expired. For instance, had an unexpired agreement been involved, a decision on the successorship issue would have had relevance to the subsequent conduct of the parties.

In Wiley the grievances concerned disputes arising before the agreement expired or rights which vested during the life of the agreement. An arbitration ruling against the union on these grievances would make it unnecessary to decide the successorship issue since even the predecessor would not have been bound. However, the Court's failure to retain jurisdiction by staying the action pending an arbitration award on the merits of the disputes indicates that this rationale did not influence the Court. The Court could still have decided to allow the arbitrator to decide that successorship issue subject to later judicial review although, again, there is nothing in the opinion to support this possibility. Moreover, such a disposition would be inconsistent with the general rule of arbitration law, that an arbitration award cannot be reviewed if the court disagrees on the merits. ${ }^{55}$ Admittedly, the successorship issue is distinguishable from issues concerning interpretation of the agreement, but the policy of finality of the arbitration award is the same for both. If the successorship issue is to be a question for the courts rather than for the arbitrator, there seems to be little justification for not having the court decide the issue at the outset rather than sending it through arbitration to be climaxed by judicial review.

It may be that the Court was proceeding cautiously, because even its decision to compel arbitration was a sharp break with the past in an area of law noted for its complexities and concealed repercussions. But there is no indication that the decision was prompted by judicial restraint in the sense that the Court was consciously avoiding a decision on a prematurely raised issue.

\section{Arbitration as a Federal Policy}

A more plausible interpretation of Wiley's failure to decide the successorship issue is that the Court, as a matter of substantative federal labor policy, preferred arbitrators to the courts as the proper tribunal for resolving such disputes. This policy is well established in ordinary section 301 (1960).

55 United Steelworkers v. Enterprise Wheel \& Car Corp., 363 U.S. 593, 596 
breach of contract actions; thus, upon objections by the defendant to judicial determination, the Court will stay the action and order arbitration if the agreement contains an arbitration clause. ${ }^{56}$ The basis for this judicial deference is the arbitrator's experience in deciding the merits of a dispute involving interpretation of the contract, particularly when the contract is silent or ambiguous on the point. . $^{57}$

Adoption of this approach to the successorship issue would mean that the courts would limit themselves to a loose application of the continuity standard, and if the successor arguably came within the test, the courts would order arbitration. The arbitrator would then be free to reconsider the continuity standard as it bears upon the factual disputes of the parties. Presumably the arbitrator would be at liberty to rule that the continuity of operations was so extensive as to bind the successor with the entire contract or that the extent of continuity warranted the imposition of some but not all of the predecessor's contractual obligations.

Although this analysis is in accord with the Court's disposition of Wiley, there is no clear indication from the opinion that this rationale was in fact being employed, although in a footnote the Court expressed concern that problems could arise which would require for solution the expertise of an arbitrator. ${ }^{58}$ However, even if the Court was not consciously following this rationale, the successorship issue has the potential for raising issues of sufficient complexity to warrant the express adoption of the rationale at the first opportunity.

One complexity not presented by the facts of Wiley is the disruption of the successor's labor relations caused by the integration of predecessor's employees into a successor's preestablished operation, as often results from a merger or consolidation. Forcing the successor to adhere flatly to the predecessor's agreement could result in disparate treatment for the predecessor's employees, and the resentment of the successor's employees could seriously disrupt the successor's labor relations. ${ }^{59}$ These problems would not be likely to arise in a situation such as Wiley, which, although involving a merger and integration of operations, did not involve a union representing the successor's prior employees; nor would these problems arise in situations such as the successor's purchase of the plants of the predecessor, where the integration problem could be avoided by considering these plants as a separate bargaining unit. However, the Court in Wiley, although aware of the problems posed by integration, ${ }^{60}$ did not attempt to

56 Drake Bakeries, Inc. v. Local 50, Bakery Workers, 370 U.S. 254 (1962). (1960).

57 United Steelworkers v. Enterprise Wheel \& Car Corp., 363 U.S. 593, 597

58376 U.S. at $551-52$ n.5.

50 Preferential treatment of the predecessor's employees, if represented by a union, could be the basis for a $\S 8$ (a) (3) unfair labor practice charge of discrimination filed by the successor's prior employees against the successor. These employees could contend that the discrimination would encourage membership in the union representing the predecessor's employees. See National Labor Relations Act \& 8(a) (3), 49 Stat. 452 (1935), as amended, 29 U.S.C. $\$ 158$ (a) (3) (Supp. V, 1964).

60376 U.S. at $551-52$ n.5. 
differentiate these problems from those raised by the facts at hand; the actual dispositon, although far from conclusive, suggests that further successorship cases will be accorded identical treatment, whether or not they involve integration problems.

\section{The Wiley Rule in the Lower Courts}

Despite the implications of the Wiley opinion that the Court purposely avoided more than a threshold determination of the successorship issue, two circuit courts of appeals directly decided the successorship issue shortly after Wiley. ${ }^{61}$ In both cases the collective bargaining agreement had not expired, and the successor had refused to comply with the provisions of the agreement. ${ }^{62}$ In Wackenhut Corp. v. International Union, Plant Guard Workers, the Ninth Circuit held that the successor was fully bound to fulfill the predecessor's obligations, including the duty to arbitrate. ${ }^{63}$ In United Steelworkers v. Reliance Universal, Inc., the Third Circuit indicated that the successor was bound, but the court ordered arbitration, ${ }^{\text {, }}$ suggesting that the arbitrator should modify the contractual obligations if new circumstances would make it inequitable strictly to enforce the agreement.

One justification for the decisions in these cases is their involvement with a purchase of the predecessor's assets which, since presenting no integration issues, allows for judicial competence in deciding the successorship issue. Furthermore, a decision by the court on the successorship issue would eliminate the two-step procedure of the court initially applying a threshold standard of continuity and then having an arbitrator apply the same test, possibly with divergent results. Moreover, the arbitrator's relative freedom to ignore prior decisions presents a greater risk of differing results on similar facts.

However, it is an oversimplification to assume that in situations such as purchases of assets the problems are so lacking in complexity that they can be resolved by the courts, while other situations, such as mergers, require the expertise of an arbitrator. While the need for the flexibility of the arbitration process is most apparent when there are problems of integrating two employee groups, this need is also present in other situations as well. The all-or-none approach of Wackenhut hardly seems conducive to the establishment of a continuity in the employment relationship.

61 United Steelworkers v. Reliance Universal, Inc., 335 F.2d 891 (3d Cir. 1964); Wackenhut Corp. v. International Union, Plant Guard Workers, 332 F.2d 954 (9th Cir. 1964).

62 In United Steelworkers v. Reliance Universal, Inc., 335 F.2d 891 (3d Cir. 1964), wages, insurance coverage, vacation, and holiday arrangements were in dispute. Brief for Appellant, p. 3. In Wackenhut Corp. v. International Union, Plant Guard Workers, 332 F.2d 954 (9th Cir. 1964), the successor refused to comply with wage, checkoff, and union shop provisions of the predecessor's agreement.

63 Id. at 958. 1964).

64 United Steelworkers v. Reliance Universal, Inc., 335 F.2d 891, 895 (3d Cir. 
Even if the Wackenhut approach is thought to be preferable to arbitrating the successor's obligations, it still must be determined whether Wiley forecloses the lower federal courts from active participation in these issues. If the accepted rationale for Wiley is that arbitration is to be the preferred means of resolving these disputes, the Wackenhut approach seems incorrect. If it becomes established that the Court in Wiley refrained from deciding the extent of the successor's obligation because of the expired contract, the union's narrow allegation of breach, or because of judicial reluctance to move too swiftly, development of the Wackenhut approach would remain open.

\section{The Role of the Arbitrator}

The application of a Wiley approach to a case involving the integration of rival employee groups would of necessity vest broad powers in the arbitrator in reaching a satisfactory solution. He must have the power to determine which of the terms of the predecessor's agreement would, if continued, have an adverse impact upon the employment relationship between the successor and his original employees and to refuse to apply such provisions.

However, the court in Reliance suggested a far broader power to be given the arbitrator, the ability to modify the terms to avoid inequitable applications. Applied to situations other than those involving competing employer groups, there is little need for such sweeping powers. This is not the ordinary view of the powers of an arbitrator; normally, they interpret an agreement and are not empowered to change or ignore the contract terms. ${ }^{65}$ Ignoring a term has the same impact as modifying it, since the employer would then be free, subject to a duty to bargain, to take unilateral action. Finally, the successor would seem to be protected from gross inequities by the continuity standard in the hands of the court or arbitrator.

\section{Agreements Without an Arbitration Clause}

Despite the heavy reliance by Wiley on the arbitration policy announced in United Steelworkers v. Warrior \& Gulf Nav. Co., ${ }^{66}$ the absence of an arbitration clause should not preclude enforcement of an agreement against a successor employer. Arbitration is only a preferred method of (1960).

65 United Steelworkers v. Enterprise Wheel \& Car Corp., 363 U.S. 593, 597

The court in Reliance cited United Steelworkers v. Warrior \& Gulf Nav. Co., 363 U.S. 574 (1960), and Cox, Reflection Upon Labor Arbitration, 72 HARv. L. REv. 1482 , 1493-98 (1959), as supporting the view that an arbitrator can modify the agreement. 335 F.2d at 895 . However, these authorities present the position that an arbitrator can in effect expand a collective bargaining agreement only when it is silent or ambiguous on a particular issue. They do not support a change of contract terms which are already in the agreement.

66363 U.S. 574 (1960). 
settling disputes and is not a prerequisite to a section 301 suit. Thus in Atkinson v. Sinclair Ref. Co., ${ }^{67}$ the arbitration clause covered only employee grievances and not those of the employer, yet the court permitted the employer to bring a damage action for breach of a no-strike clause.

The relief obtainable by a union in the absence of an arbitration clause will necessarily differ from that obtainable when the collective bargaining agreement contains such a clause. In the latter case the court can order arbitration when the union seeks it, ${ }^{68}$ or can order arbitration and stay the action pending the outcome when a party seeks damages for a breach and the defendant objects and requests arbitration. ${ }^{69}$ In the absence of an arbitration clause, the union must seek to compel the successor's performance through an action for specific performance, ${ }^{70}$ by a declaratory judgment, ${ }^{71}$ or by seeking damages. ${ }^{72}$ It is clear that section 301 does not repeal the Norris-La Guardia Act prohibition of injunctions in labor disputes when the employer seeks to enjoin a strike violating a no-strike provision of the contract. ${ }^{73}$ Although one court has gone so far as to say that Norris-La Guardia would not prevent injunctions against employers, but was designed to protect employees and unions, ${ }^{74}$ other courts have

67370 U.S. 238 (1962).

68 John Wiley \& Sons v. Livingston, 376 U.S. 543 (1964).

${ }^{69}$ Cf. Drake Bakeries, Inc. v. Local 50, Bakery Workers, 370 U.S. 254 (1962).

70 Retail Clerks v. Alfred M. Lewis, Inc., 327 F.2d 442 (9th Cir. 1964); Independent Petroleum Workers v. Esso Standard Oil Co., 235 F.2d 401 (3d Cir. 1956); Local 641, Amalgamated Butcher Workmen v. Capital Packing Co., 32 F.R.D. 4 (D. Colo. 1963).

71 See Black-Clawson v. International Ass'n of Machinists, 313 F.2d 179 (2d Cir. 1962); Fried v. Glenn Elec. Heater Corp., 198 F. Supp. 248 (D.N.J. 1961) (dictum); Kennamental, Inc. v. International Union, UAW, 161 F. Supp. 362 (W.D. $\mathrm{Pa} .1958$ ) (dictum). This is the view of a substantial majority of the courts. See cases cited in Black-Claweson, supra at 181, for the contrary view.

72 Atkinson v. Sinclair Ref. Co., 370 U.S. 238 (1962).

${ }^{73}$ See Sinclair Ref. Co. v. Atkinson, 370 U.S. 195 (1962).

Since $\$ 301$ provides not exclusive, but concurrent jurisdiction, state courts have jurisdiction. Some states believe that they have jurisdiction to enjoin strikes in breach of contract since the Norris-La Guardia Act applies only to federal courts. See, e.g. McCarroll v. Los Angeles County Dist. Council of Carpenters, $49 \mathrm{Cal} .2 \mathrm{~d}$ 45, 315 P.2d 322 (1957), cert. denied, 355 U.S. 932 (1958); C. D. Perry \& Sons v. Robilotto, 39 Misc. 2d 147, 240 N.Y.S.2d 331 (Sup. Ct. 1963); Shaw Elec. Co. v. International Bhd. Elec. Workers, No. 301, Pa., March 22, 1965.

It is currently disputed whether a defendant in an injunction suit in a state court may remove to a federal court and obtain a dismissal of the complaint because of the Norris-La Guardia Act. See American Dredging Co. v. Local 25, Int'1 Union of Operating Eng'rs, 338 F.2d 837 (3d Cir. 1964), cert. denied, 85 Sup. Ct. 941 (1965).

74 Brotherhood of Locomotive Eng'rs v. Baltimore \& O.R.R., 310 F.2d 513 (7th Cir. 1962). The court added that the purpose of Norris-La Guardia was to protect unions and employees, except for two isolated exceptions. Id. at 518; see NorrisLa Guardia Act \$ 3, 47 Stat. 70 (1932), 29 U.S.C. \$ 103 (1958) (agreements not to join or withdraw from labor or employer organization unenforceable); Norris-La Guardia Act § 4(b), 47 Stat. 71 (1932), 29 U.S.C. \$104(b) (1958) (injunctions against persons joining a labor or employer organization are prohibited). 
declared that mandatory injunctions ordering arbitration ${ }^{75}$ or specific performance ${ }^{76}$ of contract obligations do not violatate Norris-La Guardia.

Difficult problems may arise over the proper interpretation of a clause in the collective bargaining agreement. It may well be that a court is less able than an arbitrator to satisfactorily resolve such issues, but in the absence of an arbitration clause, section 301 imposes a duty upon the courts to grapple with these problems. When the language of an agreement does not clearly dispose of an issue, the court must resort to analogies from other aspects of the agreement or from past practices as in any nonsuccessor section 301 suit, with the further task of deciding whether the successor can be bound by such circumstances. In fact inadequate judicial treatment of labor disputes may expedite the inclusion of arbitration clauses into collective bargaining agreements, thus effectuating the policy of Warrior. Moreover, judicial resolution of contract disputes may remove the advantage to economically strong parties in not having arbitration clauses. In this way section 301 can promote the industrial stability proclaimed in Warrior to be an objective of the national labor policy.

\section{A Notice Requirement}

Since the union in Wiley made known its position well before the merger, no question was raised whether pretransaction notice to the successor of the union's claims is necessary before a collective bargaining agreement can be enforced against him. However, the Court in Wiley left this question open by cautiously refusing to "rule out the possibility that a union might abandon its right to arbitration by failing to make its claims known." 77 Despite this deliberate reservation, neither of the two courts of appeals decisions following Wiley discussed the notice issue. The omission was of comparative insignificance in Wackenhut, ${ }^{78}$ since the union itself was unaware of the sale transaction until after it was completed. The facts of Reliance ${ }^{79}$ are not as clear, but they do indicate that a notice problem was presented. The predecessor there complied with a Federal Trade Commission order that the predecessor sell a plant, and "thereafter the union demanded that [the successor] . . . honor the outstanding collective bargaining agreement." 80 The failure of the court to discuss the timeliness of the union's demand suggests a rejection of at least a strict notice requirement and, perhaps, of any requirement.

75 Textile Workers v. Lincoln Mills, 353 U.S. 448, 451 (1957). Although an order to arbitrate is proper, one court has held that it would violate the NorrisLa Guardia Act to enjoin an alleged breach of contract pending arbitration. Publishers' Ass'n v. New York Mailers' Union, 317 F.2d 624 (2d Cir. 1963), vacated on other grounds, 376 U.S. 775 (1964).

76 Retail Clerks Union v. Alfred M. Lewis, Inc., 327 F.2d 442 (9th Cir. 1964). 77376 U.S. at 551.

78332 F.2d 954, 956 (9th Cir. 1964).

79335 F.2d 891 (3d Cir. 1964).

$80 \mathrm{Id}$. at 893 . 
There would seem to be little value in a rigid requirement of union notification. Since the union may often have only incomplete knowledge of negotiations or of potential successors, a post hoc determination whether the union should have given notice risks an unfair second-guessing of the union. Moreover, the existence of Wiley reduces the necessity of a notice requirement by creating an awareness of potential union demands. There may be, however, some situations in which a lack of a notification requirement would be unjust to a potential successor; for example, union claims based on unwritten past practices or interpretations of the collective bargaining agreement would not be apparent from a reading of the agreement. Moreover, notice of such claims would have to be specific to be of value to the successor; a clause in the agreement purporting to bind successors or a general statement from the union asserting that the successor was obligated to fulfill the predecessor's duties would not suffice. ${ }^{81}$

\section{E. Employer Actions}

In normal section 301 actions both parties are bound by the collective bargaining agreement, and suits may be instituted by employers, unions, or individual employees. ${ }^{22}$ In Wiley and both courts of appeals decisions, the action was brought by the union; it is therefore an open question whether the Wiley rule should be applied to suits by the employers. In a suit by a successor employer for breach by the union of the predecessor's agreement, the union in defense could contend that the agreement was no longer binding. The employer's claim would be that sufficient continuity existed despite the change in ownership to bind the union to the new employerfor example, to obtain adherence to a no-strike clause or to collect damages for its breach. The union's purpose in contesting its contractual obligations must be, if its majority status were secure, to obtain a more favorable contract from the successor at the bargaining table.

A distinction can be made between holding a successor employer bound and holding the union bound under the same contract. The successor had available a choice of not entering into the transaction with the predecessor if he objected to the collective bargaining agreement. The union, however, does not have this alternative. However, this fact should not relieve the union of its obligations under the contract: the policy of peaceful settlement has equal application regardless of which party seeks to avoid the contract. This would not seriously hinder the union's inter-

81 In Wiley it was established that disputes concerning the arbitration procedure are to be decided by the arbitrator, 376 U.S. at 555-59. It was previously well established that substantive arbitrability is a court decision. Atkinson v. Sinclair Ref. Co., 370 U.S. 238, 241 (1962). If notice is to be an absolute requirement, it could be considered part of the grievance-arbitration procedure and thus not a question for the courts, while if viewed as an equitable consideration used to defeat the union's claim when the successor might not reasonably have been able to anticipate the grievance in question, it would seem properly to be a question of substantive arbitrability for the courts.

82 Smith v. Evening News Ass'n, 371 U.S. 195 (1962). 
ests, as ninety-five percent of all collective bargaining agreements are not longer than three years in duration..$^{83}$

\section{F. Predecessor-Successor Relationships to Which Wiley Might Not Apply}

In contrast to the common-law rules which were framed in terms of the form of transaction, ${ }^{84}$ the focus of the approach in Wiley was upon the employee-employer relationship. ${ }^{85}$ Thus, although Wiley involved a merger, the first two cases to apply Wiley involved a purchase of assets. ${ }^{86}$ Nevertheless, to the extent that other forms of predecessor-successor relationships present different interests, the balancing process described by the Court may require a subordination of the national labor policy deemed paramount in the Wiley situation.

\section{Bankruptcy}

One source of potential conflict with the Wiley policy is the Bankruptcy Act. The successor issue can arise in several of the various types of bankruptcy proceedings, although the issue would not always be the same. The standard proceeding involving adjudication of bankruptcy, liquidation of the bankrupt's estate, and bankruptcy sale ${ }^{87}$ could give rise to a successor who previously was a total stranger to the predecessor's enterprise. The issue can also arise as a result of a reorganization under chapter $\mathrm{X}^{88}$ or an arrangement under chapter $\mathrm{XI}^{89}$ although the successor in such proceedings would be little more than the alter ego of the predecessor. In the former instance it is the power of the bankruptcy trustee to sell free and clear of the predecessor's oligations, ${ }^{90}$ which presumably includes a collective bargaining agreement, that creates the policy conflict. Similarly, in the latter instances, it is the power of the court to approve a plan repudiating existing executory contracts ${ }^{91}$ that conflicts with $W$ iley.

In weighing these conflicting policies the courts, prior to Wiley, seemed to regard the federal bankruptcy policy as paramount; therefore, a

83 A 1960 BNA survey indicated that $13 \%$ of agreements last one year, $43 \%$ two years, and 39\% three years. BNA LAB. REL. REP. LRX 97 (1954).

84 See notes 15-23 supra and accompanying text.

85 See notes 5-9 supra and accompanying text.

86 United Steelworkers v. Reliance Universal, Inc., 335 F.2d 891 (3d Cir. 1964); Wackenhut Corp. v. International Union, Plant Guard Workers, 332 F.2d 954 (9th Cir. 1964).

87 See Bankruptcy Act $\$ 70(f), 76$ Stat. 572 (1962), 11 U.S.C. \$110(f) (Supp. V, 1964); Bankruptcy Act $\$ 70(\mathrm{~g})$, 52 Stat. 882 (1938), 11 U.S.C. \& 110 (g) (1958); General Orders in Bankruptcy 18, 305 U.S. 688 (1939). (1958).

88 See Bankruptcy Act $\S \S 111-17,52$ Stat. $884-85$ (1938), 11 U.S.C. $\S \$ 11-17$

89 See Bankruptcy Act $\S 311-16,52$ Stat. 906 (1938), 11 U.S.C. \$\$711-16 (1958).

90 See Van Huffel v. Harelrode, 284 U.S. 225 (1931); Oppenheim, Sales of Property in Bankruptcy Free and Clear of Encumbrances, 29 ILL. L. REV. 67 (1934).

91 Bankruptcy Act $\$ 116(1), 52$ Stat. 885 (1938), 11 U.S.C. $\$ 516(1)$ (1958) (reorganization) ; Bankruptcy Act $\$ 313(1), 52$ Stat. 906 (1938), 11 U.S.C. §713(1) (1958) (arrangements). 
court could relieve a successor of any collective bargaining obligations of the predecessor. ${ }^{92}$ However, the union does have the opportunity to present its claims; the court may approve a compromise that relieves a successor of certain economic obligations while leaving him bound by other collective bargaining provisions, such as job security and seniority.

\section{Private Reorganizations}

An employer might also seek a voluntary reorganization of the enterprise in a period of economic hardship. Under the contract-corporation analysis the successor to a reorganization was treated as the alter ego of the predecessor and the rights of creditors were preserved. ${ }^{93}$ However, there are a variety of reorganization schemes. If only minor changes in the capital structure are involved, there would be no compelling policy to override the Wiley result. However, the reorganization might be substantial and necessary for the survival of the enterprise. If the successor to the reorganization were held responsible for the collective bargaining obligations of the predecessor under the alter-ego rule or the Wiley rule, it might mean the impossibility of continued operations.

Normally, an employer cannot avoid his own collective bargaining agreement for economic reasons. However, economic motivation becomes significant when an employer relocates or goes out of business. The Board in unfair labor practice proceedings has had difficulty articulating the standards of lawful economic motives and unlawful antiunion discriminatory motives, and although the courts believe that even the latter are lawful for employers going entirely out of business, ${ }^{94}$ it is clear that a pure economic motive is a valid justification for relocation or going out of business. ${ }^{95}$

A voluntary reorganization can clearly be distinguished from an economic shutdown in that the employment relationship is not ended. However, the shutdown decisions may indicate that the courts consider economic survival to be a compelling enough consideration to relieve the successor of any obligation to perform the collective bargaining agreement of the predecessor.

A successor by virtue of a purchase at a judicial sale of an enterprise presents analogous problems. The common-law courts considered this a normal purchase of the assets of the predecessor ${ }^{96}$ and applied the rule that the successor was not bound by the predecessor's obligations. ${ }^{97}$ In this

92 See In the Matter of Kalber Bros., 173 F. Supp. 83 (S.D.N.Y. 1959); cf. Nathanson v. NLRB, 344 U.S. 25 (1952).

${ }_{93}$ E.g., Meridian Amusement Co. v. Home Theater Co., 215 Ill. App. 479 (1919); Bank of Murray v. Farmers' Bank, 257 Ky. 251, 77 S.W.2d 624 (1934); 15 FLETCHER, PRIVATE CORPoRATIONS $\$ \$ 7305,7329$ (Wolf rev. ed. 1961).

94 See Darlington Mfg. Co. v. NLRB, 325 F.2d 682 (4th Cir. 1963), denying enforcement of 139 N.L.R.B. 241 (1962), aff'd in part, 33 U.S.L. WEEK 4292 (U.S. March 30, 1965).

${ }_{95}$ Mount Hope Finishing Co. v. NLRB, 211 F.2d 365 (4th Cir. 1954) (plant removal); Diaper Jean Mfg. Co., 109 N.L.R.B. 1045 (1954), enforced per curiant, 222 F.2d 719 (5th Cir. 1955).

06 15 FIETCHER, op. cit. sipra note $93, \S 7333$ \& cases cited.

97 See notes 15-23 sipra and accompanying text. 
situation the union's interest as set forth in Wiley conflicts with the interests of other creditors. If the successor is forced to assume the collective bargaining agreement of the predecessor, the effect may be to diminish the purchase price from that obtainable if the successor were not bound. There is presently no indication as to how the courts would reconcile this conflict. It would seem, however, that the policy favoring creditors here involved is not as strong as that of the federal bankruptcy policy and therefore should not necessarily be paramount to the federal labor policy as set forth in Wiley.

\section{IMPACt of the Wiley RuLE \\ A. Transferability of Property}

If requiring a successor to be bound by the predecessor's collective bargaining agreement would be so onerous to the successor as to persuade him in many cases not to complete the transaction, the Wiley rule could be accused of hindering the transferability of property. Such a successor might object to being bound for several reasons. First, he might have a general hostility towards unions, although this objection should not receive consideration, since a successor, even without $W$ iley, would be faced with unionization if the union represents a majority of employees in the new unit. If the union does not represent a majority of the employees, the successor will be forced to deal with the union only for a limited period, since a contract is only a bar to a representation election for a maximum of three years. ${ }^{98}$ Presumably this period will include the time expired when the predecessor was still a party to the agreement.

The successor might also object to specific provisions of the agreement. This objection may be legitimate even given the probability that the agreement will expire in a short time. ${ }^{99}$ If the union represents a majority of the employees in the new unit, the successor will be forced to bargain with the union following the termination of the predecessor's agreement. As a matter of bargaining tactics, it would be harder for a successor to change the objectionable terms of the predecessor's agreement if the successor had been bound by this agreement than if the successor were bargaining with the union without previously having been bound. However, this disadvantage would not seem likely to have a substantial effect on the transferability of property. The collective bargaining agreement of the predecessor is but one of many elements of the predecessor's enterprise. With the possible exception of marginal cases, it would seem probable that the successor would continue with the transaction and merely adjust his purchase price accordingly. This would place the burden of the objectionable provisions on the predecessor-where they rightly belong.

88 General Cable Corp., 139 N.L.R.B. 1123 (1962).

99 See note 83 supra. 


\section{B. Successor's Attempt To Avoid the Wiley Rule}

Awareness of the Wiley rule might cause successors to change the form of their transaction with the predecessor. Rather than acting in such a way that the continuity standard would be satisfied, the successor may attempt to limit his purchase to those assets which would enable him to avoid being bound by the contract. If this happened with any frequency, the impact of Wiley would be to disrupt rather than promote continuity of the employment relationship. However, this difficulty seems more apparent than real, for it is not likely that a successor interested in acquiring a going concern would be satisfied with dismantling and removing the physical assets. In borderline transactions, from the continuity standpoint, the successor would be better able to tailor the transaction to fall outside of the continuity test, but such small alterations would not jeopardize the entire employment relation.

\section{Disruption of Voluntary Collective Bargaining}

The small amount of litigation in the pre-Wiley era suggests that the parties reached some form of voluntary arrangements concerning the collective bargaining agreements. It may be more difficult to make such settlements after Wiley because the unions can insist on the legal rights established in Wiley, perhaps even full recognition of the labor agreement. Moreover, until the test of continuity is clearly defined and settled by courts and arbitrators, there perhaps will be increased litigation with its resulting expense. However, even if the making of voluntary arrangements will be hindered, resort to economic pressure following impasses in the negotiations of these arrangements would likewise be lessened. Implicit in Wiley is the decision that the balance is in favor of industrial stability and the abandonment of economic pressure. Admittedly, the judicially enforced industrial stability created by Wiley may be only temporary, there being no guarantee that economic struggles will not occur upon the expiration of the predecessor's agreement. However, this period will provide time for the parties to establish a firm foundation for the mature negotiation of a new agreement when the predecessor's agreement expires. ${ }^{100}$

Harry E. Reagan, III

100 Brief for the AFL-CIO as Amicus Curiae, p. 11, John Wiley \& Sons, v. Livingston, 376 U.S. 543 (1964); Note, 60 YALE L.J. 1026, 1034 (1951). 